\title{
Extension of Shelf Life of Enriched Shrikhand Using Continues Microwave Processing
}

\author{
M. Venkatesh", T.C. Soumyashree, M. Rajanna and A.R. Praveen
}

Dairy Technology Department, Dairy Science College, Hebbal, Bengaluru-560 024, India

*Corresponding author

\section{A B S T R A C T}

\section{Keywords}

Shrikhand, WPC and Microwave processing

Article Info

Accepted:

26 March 2018

Available Online:

10 April 2018
Enriched shrikhand was prepared by blending WPC at 3, 4, 5 and 6 per cent levels and Maximum overall acceptability score of 8.20 was awarded to the sample prepared by using WPC at 5 per cent level and the sample was subjected to microwave treatment. There was a significant decrease in the per cent of moisture content of T3 sample (38.73\%) compared to control $(41.53 \%)$. The higher per cent of protein was recorded in WPC incorporated sample T3 (9.98) compared to control (7.12). The control sample had significantly higher levels of FFA $(0.342 \mu$ equl/g) compared to T3 $(0.281 \mu$ equl/g). The control sample had yeast and mould counts of $1.20\left(\log _{10} \mathrm{cfu} / \mathrm{g}\right)$ and increased to $1.95\left(\log _{10} \mathrm{cfu} / \mathrm{g}\right)$ during storage. Microwave treatment would have restricted the growth of microorganisms. The sample T3 was secured significantly $(\mathrm{P}<0.05)$ highest body and texture score of 27.42 than the control 26.10 due to added WPC and microwave treatment further improves the texture of the product. Therefore control sample was not accepted by the judges on $42^{\text {nd }}$ day.

\section{Introduction}

Fermented milks are known for their excellent nutritive and therapeutic properties, particularly when selected cultures of lactic acid bacteria are used as starters for fermenting milk products. It has been estimated the nearly 8.00 per cent of the total milk produced in India is utilized for the preparation of fermented milk products (Aneja, et al., 1997).

Shrikhand has originated in Western India. It is obtained from dahi by partial drainage of whey, to which sugar, fruits and nuts are added. It derives its name from Sanskrit word
"Shikharini". It contains most of the valuable constituents of milk like casein in a highly digestible form, fat, minerals and fat soluble vitamins. Chaudhury and Aneja (1986) reported that the nutritional quality of proteins in chakka, in terms of Biological Value (BV), Digestibility Coefficiency (DC) and Net Protein Utilization (NPU) is similar to that of casein. The protein efficiency ratio values for chakka were found to the antagonistic action of lactic acid bacteria (LAB) towards less desirable microorganisms of public health or spoilage organisms.

The conventional shrikhand making technology is a tedious and time-consuming 
process. In traditional method of preparation of shrikhand, most of the whey proteins are lost during whey drainage in chakka making stage. Whey contains about 20 per cent of milk proteins of high biological value. One hundred gram of whey protein contains about $2.5 \mathrm{~g}$ of cystine and $2.8 \mathrm{~g}$ of cysteine. Whey protein contains all the essential amino acids including isoleucine, lysine, threonine, and tryptophan (Irvine et al., 1984).

Whey protein possesses good functional properties such as foaming, emulsifying, gelling and water binding. Since whey protein possesses excellent nutritional and functional properties they are used in various foods like soups, sauces, toppings and dressings, ready to eat snacks foods, confections and beverages (Gupta and Thapa, 1991).

Microwave processing used in the food industry for heating are the Industrial, Scientific and Medical (ISM) frequencies of $2450 \mathrm{MHz}$ or $915 \mathrm{MHz}$, corresponding to 12 $\mathrm{cm}$ or $35 \mathrm{~cm}$ in wavelength. Microwaves generated by Magnetron that converts electrical energy $(60 \mathrm{~Hz})$ into an electromagnetic field with centres of positive and negative charges. Majority of foods contain a substantial proportion of water. The molecular structure of water consists of a negatively charged oxygen atom and positively charged hydrogen atoms and it forms an electrical dipole. When microwave is applied to a food, dipole in the water attempt will orient themselves to the field. Since the rapidly oscillating electric field charges from positive to negative and back again several million times per second, the dipoles attempt to follow and these rapid reversals create frictional heat. The increase in temperature of water molecule heats surrounding components (Ohlsson and Bengtsson, 2002). Microwaves are reflected by metals, transmitted by electrically neutral materials such as glass, most plastics, ceramics and paper, and absorbed by electrically charged materials (Mullin, 1995).

There is only scanty information available literature on the microwave processing to enrich and enhance the shelf life of shrikhand and similar products. Hence, investigation has to be taken to increase the shelf life of shrikhand by employing novel processing techniques like continuous microwave processing without affecting its physicochemical, microbiological, textural and organoleptic properties.

\section{Materials and Methods}

Cow milk was procured from KVAFSU Dairy Farm, Hebbal, Bengaluru was used for shrikhand preparation. Skim milk - Fresh cow milk preheated to $35 \mathrm{oC}$ was subjected to centrifugal separation using Alfa Laval Cream Separator (AE 108) at Students Experimental Dairy Plant (SEDP) of the Dairy Science College, KVAFSU, Hebbal, Bengaluru. Skim milk thus obtained was used for the preparation of shrikhand. Cream - Fresh cow milk preheated to $35^{\circ} \mathrm{C}$ was subjected to centrifugal separation using Alfa Laval Cream Separator (AE 108) at Students Experimental Dairy Plant (SEDP) of the Dairy Science College, KVAFSU, Hebbal, Bengaluru. Cream obtained with 65 per cent fat was used for standardization of raw milk to desired fat level in milk for the preparation of shrikhand. Skim milk powder (SMP): "Sagar" brand spray dried SMP procured from the local market was used to make up the Solids- NotFat (SNF) content of milk for the preparation of shrikhand. Sugar was procured from local market.

\section{Starter culture}

Mixed strains of Lactococcus lactis and Lactococcus lactis var diacetilactis (1:1) procured from the Dairy Microbiology 
Department of the Dairy Science College, KVAFSU, Hebbal, Bengaluru was used for culturing milk.

\section{Chemicals}

Analytical grade chemicals (Merk) procured from local market, Bengalore were used in the present study.

\section{Preparation of control and enriched shrikhand}

The control and enriched shrikhand were prepared as per procedure followed by Bogra and Mathur (2000) with slight modification. Shrikhand was prepared from fresh cow milk, which was standardized using cream, and SMP to $4.50 \%$ fat and $8.50 \% \mathrm{SNF}$. The standardized milk was heated to $95^{\circ} \mathrm{C}$ for 5 min, cooled to $30^{\circ} \mathrm{C}$ and inoculated with Lactococcus lactis and Lactococcus lactis var diacetilactis (1:1) at the rate of $2.00 \%$ of the volume of milk. It was then incubated for $16 \mathrm{~h}$ at $30^{\circ} \mathrm{C}$.

The curd thus obtained was hanged in a muslin cloth for $12 \mathrm{~h}$ for the removal of whey. The resultant semisolid mass called chakka was then added with good quality ground sugar at the rate of $40.00 \%$ of the weight of chakka and kneaded to get a smooth consistency. For the manufacture of enriched shrikhand, WPC was added to chakka at the rate of $3.00,4.005 .00$ or 6.00 per cent (Flow chart 1and 2).

Process optimization to enhance the shelflife of shrikhand by continuous microwave processing

Shrikhand of $100 \mathrm{~g}$ was packaged by using PET/PE laminate and were exposed to microwave heat treatment in the continuous microwave processor. Trials were carried out to optimize processing parameters w.r.t. conveyor speed $(1.50 \mathrm{~m} / \mathrm{min})$, duration of exposure $(40 \mathrm{sec})$ and final temperature $\left(70^{\circ} \mathrm{C}\right)$ attained at a fixed microwave power level of 1 $\mathrm{kW}$ which corresponded to a power density of $10 \mathrm{~W} / \mathrm{g}$. After treatment, the products were subjected to sensory evolution by a panel of 5 judges to know the organoleptic quality of shrikhand. Based on the sensory evaluation scores of shrikhand, best processing parameters were selected and was used for final study.

\section{Packaging material}

The packing material used for packaging shrikhand samples was procured from Shakthi Packaging, Bengaluru. The packaging material had two layers of polyethylene teraphthalate/polyethylene (PET/PE, $12 / 54 \mu \mathrm{m})$. This packaging material was specifically chosen for its low microwave absorption properties. The thickness of the material was $66 \mu \mathrm{m}$. the size of the packaging material was $20 \mathrm{X} 14 \mathrm{~cm}$ (LXB).

\section{Analytical equipments}

Laboratory equipments Analytical equipments such as Hot air oven (Scientific Industries, Bangalore), Autoclave (York Scientific Industries, Delhi), Digital pH meter (Elico, Model-LI 127, Bangalore), Bacteriological incubator (Serwell Industries Inc., Bangalore), Water bath, (Kemi, Model KWB 180, Mumbai), Electronic balance (Mettler-Toledo India Pvt. Ltd., Mumbai), etc. were used for chemical and microbiological analysis.

\section{Processing equipment's}

\section{Microwave processor}

The continuous type microwave processor was used to process the shrikhand: Manufactured by M/s Microwave products (India) Limited, Model: MPCD/005/200304 


\section{Statistical analysis}

The results are the average of three replications was statistically analyzed by using ANOVA technique (Zar, 2003) for one way analysis with independent samples.

\section{Results and Discussion}

Effect of different levels of WPC on the quality of shrikhand

Effect of WPC on chemical composition of enriched shrikhand

The effect of various levels of WPC on chemical composition of shrikhand is depicted in Table 1. There was a significant decrease in the moisture and fat per cent of treated sample that ranged from 41.25 to 40.34 and 6.55 to 6.46 respectively, as the level of incorporation of WPC increased from 3 to 6 per cent. The decrease in the moisture and fat per cent of treated samples was mainly due to the significant increase in per cent total solids from 58.07 to 59.66 . Whereas, a significant increase in the protein per cent of treated shrikhand from 8.39 to 9.64 was also observed The incorporation of WPC was mainly responsible for this increase in protein per cent of treated shrikhand and there was a nonsignificant level increase in the per cent acidity of shrikhand samples as the level of incorporation of WPC increased from 3.00 to 6.00 per cent level. The milk solids were effectively replaced with WPC in milk bread and its physicochemical and sensory attributes were found to be enhanced (Jayaprakasha. 1998). Puranik and Gupta (1997) have reported successful utilization of 7.00 per cent WPC-60 or 10.00 per cent WPC-50 in the formulation of cake batter. Busra et al., (2014), revealed that, WPC and buttermilk powder addition improved dough properties in terms of dough stability. Protein content of the flat breads increased up to 14.60 per cent with WPC usage.
Effect of various levels of WPC on the sensory characteristics of enriched shrikhand

The enriched shrikhand was prepared by blending WPC at 3.00, 4.00, 5.00 and 6.00 per cent levels and showed no significant difference between the colour and appearance scores at all the levels of WPC incorporation compared to control and as well as between the treatments. There was a significant increase in the body and texture score (8.31) of enriched shrikhand prepared by blending WPC at 5.00 per level compared to control (7.65). Hence, incorporation of WPC at 5.00 per cent level was found to be optimum. At higher levels of WPC incorporation product becomes viscous and thick in its consistency. Hence this could be the reason for awarding significantly lower score for the shrikhand sample prepared by using WPC at 6.00 per cent level.

The maximum flavour score was awarded to control (8.0) and minimum (6.91) for the sample with 6 per cent WPC. But, samples prepared by using WPC upto 5.00 per cent level were showed the no significant effect on the flavour scores. The lower flavour score of the samples may be attributed to the lower per cent of fat (Table 2) in the samples at higher levels of WPC incorporation.

Maximum overall acceptability score of 8.20 was awarded to the sample prepared by using WPC at 5.00 per cent level was found to be significantly higher when compared to control. This could be due to the fact that better functional properties of WPC particularly in improvement of body and texture and better consistency. Thapa and Gupta (1992) reported that the processed cheese prepared with added WPC at 20.00 per cent level showed decline in appearance score $(\mathrm{p}<0.05)$ in addition to browning of the product. The addition of WPC increases the level of proteins in the product, enhances its hydrophilic properties and 
improves its viscosity (Tamine and Robinson, 2007). There was significant improvement in the body and texture scores of shrikhand prepared by incorporating WPC at 3.00, 4.00 and 5.00 per cent level than that of control. At 5.00 per cent level of incorporation, a significant increase in the body and texture scores was observed due to its good mouth feel, smooth and firm consistency, soft body and textural characteristics without any free moisture. But at higher levels of WPC (6.00 per cent), judges felt that shrikhand was highly viscous and drier and hence awarded lower body and texture scores for the shrikhand containing 6.00 per cent WPC.

The decline in the body and texture scores may be ascribed to incorporation of higher levels WPC in the in treated sample (Table 1) that led to higher per cent of total solids in the finished product. These results are in confirmation with the findings of Sharma, et al., (1998), who reported that a dried whey product used at lower levels (2.00 to 5.00 per cent) in dairy products contributed to the desirable mouth feel attributes. Addition of whey concentrate to more than 5.00 per cent level brought about deterioration in the quality of shrikhand in terms of flavour, consistency, body and taste (Giram et al., 2001).

Processed cheese spread with good melt ability, desired characteristics with improved spread ability can be prepared by using dried WPC at levels up to 4.50 per cent of cheese solids (Suneeta, et al., 2007).

\section{Continuous microwave treatment}

\section{Effect of continuous microwave treatment chemical quality of fresh enriched shrikhand}

The effect of continuous microwave treatment on the chemical composition of plain shrikhand and fresh enriched shrikhand was studied and the results are presented in the Table 3. There was a significant decrease in the moisture per cent of 41.50 (T2) from 41.93 (control) was observed. Similarly, T3 (40.36) from T2 (40.60) sample was also showed similar trend. This could be mainly due the generation of heat due to the effect of microwave treatment which causes the loss of little moisture from the product. There was a significant increase in the per cent protein content of T2 (8.56), T3 (8.80) was observed compared to control (7.08). This was mainly due to the addition of WPC itself contains higher proteins, whereas the fat, acidity and FFA contents of the fresh shrikhand samples of control and as well as treated samples were found to be statistically $(\mathrm{P}<0$. 05) nonsignificant (Table 3). Similar findings were also reported by Arunkumar (2006), where he revealed that There was a significant decrease in the moisture and fat per cent of treated samples that ranged from 62.09 to 57.33 and 17.90 to 16.87 respectively, mainly due to the significant increase in total solids There was a significant increase in the protein per cent of treated samples from 15.92 to 21.24 was also observed as the level of incorporation of WPC increased from 2 to 15 per cent.

\section{Storage studies on chemical composition of shrikhand}

Effect of continuous microwave treatment chemical quality of enriched shrikhand stored at $30 \pm 1^{\circ} \mathrm{C}$

Effect of continuous microwave treatment on the chemical composition of stored enriched Shrikhand at $30 \pm 1^{\circ} \mathrm{C}$ is presented in Table 4 . There was a significant decrease in the per cent of moisture content of T3 sample (38.73 $\%)$ compared to control $(41.53 \%)$ was observed on $1^{\text {st }}$ day of storage at $30 \pm 1^{\circ} \mathrm{C}$. The lower levels of moisture content in the enriched samples could be due to microwave treatment in addition to added WPC. 
Table.1 Effect of various levels of WPC on chemical composition of enriched shrikhand

\begin{tabular}{|c|c|c|c|c|c|}
\hline \multirow[t]{2}{*}{ Per cent WPC } & Moisture & Fat & Protein & Total Solids & \multirow{2}{*}{$\begin{array}{l}\text { A cidity } \\
\text { (\% LA) }\end{array}$} \\
\hline & \multicolumn{4}{|c|}{ 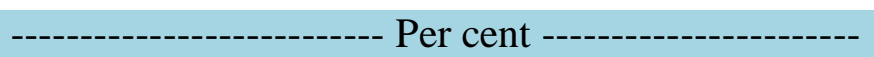 } & \\
\hline Control & $41.93^{\mathrm{a}}$ & $6.62^{\mathrm{a}}$ & $7.08^{\mathrm{a}}$ & $58.07^{\mathrm{a}}$ & 1.170 \\
\hline 3 & $41.25^{b}$ & $6.55^{b}$ & $8.39^{b}$ & $58.75^{b}$ & 1.172 \\
\hline 4 & $40.86^{\mathrm{c}}$ & $6.52^{b}$ & $8.51^{\mathrm{c}}$ & $59.14^{\mathrm{c}}$ & 1.175 \\
\hline 5 & $40.60^{d}$ & $6.50^{b}$ & $8.56^{d}$ & $59.40^{d}$ & 1.103 \\
\hline 6 & $40.34^{e}$ & $6.46^{b}$ & $8.64^{e}$ & $59.66^{e}$ & 1.184 \\
\hline C D & 0.110 & 0.02 & 0.021 & 0.23 & NS \\
\hline
\end{tabular}

Values are average of three trials, NS=Non-significant

Table.2 Effect of various levels of WPC on the sensory characteristics of enriched shrikhand

\begin{tabular}{|l|l|l|l|l|}
\hline Per cent of WPC & $\begin{array}{l}\text { Colour and } \\
\text { Appearance }\end{array}$ & $\begin{array}{l}\text { Body and } \\
\text { Texture }\end{array}$ & Flavour & $\begin{array}{l}\text { Overall } \\
\text { Acceptability }\end{array}$ \\
\hline Control (0\%) & 7.80 & $7.65^{\mathrm{a}}$ & $8.00^{\mathrm{a}}$ & $8.00^{\mathrm{a}}$ \\
\hline 3 & 7.83 & $7.70^{\mathrm{a}}$ & $7.92^{\mathrm{a}}$ & $7.81^{\mathrm{a}}$ \\
\hline 4 & 7.86 & $7.80^{\mathrm{a}}$ & $7.90^{\mathrm{a}}$ & $7.83^{\mathrm{a}}$ \\
\hline 5 & 7.88 & $8.31^{\mathrm{b}}$ & $7.85^{\mathrm{a}}$ & $8.20^{\mathrm{b}}$ \\
\hline 6 & 7.73 & $7.00^{\mathrm{c}}$ & $6.91^{\mathrm{b}}$ & $6.50^{\mathrm{c}}$ \\
\hline CD & NS & 0.23 & 0.18 & 0.28 \\
\hline
\end{tabular}

Values are average of three trials, NS=Non significant

Table.3 Effect of continuous microwave treatment on the chemical composition of fresh enriched Shrikhand

\begin{tabular}{|c|c|c|c|c|c|}
\hline \multirow[t]{2}{*}{ Treatment } & Moisture & Fat & Protein & \multirow[t]{2}{*}{$\begin{array}{l}\text { Acidity } \\
(\% \text { LA) }\end{array}$} & \multirow[t]{2}{*}{$\begin{array}{l}\text { FFA } \\
(\mu \text { equl/g) }\end{array}$} \\
\hline & \multicolumn{3}{|c|}{---------------- Per cent -------------------- } & & \\
\hline Control (0\%) & $41.93^{\mathrm{a}}$ & 6.62 & $7.08^{\mathrm{a}}$ & 1.100 & 0.317 \\
\hline T1 & $41.50^{b}$ & 6.73 & $7.27^{\mathrm{a}}$ & 1.102 & 0.320 \\
\hline T2 & $40.60^{\mathrm{a}}$ & 6.50 & $8.56^{\mathrm{b}}$ & 1.103 & 0.310 \\
\hline T3 & $40.36^{b}$ & 6.66 & $8.80^{\mathrm{b}}$ & 1.105 & 0.313 \\
\hline CD & 0.23 & NS & 0.25 & NS & NS \\
\hline
\end{tabular}

Values are average of three trials, Control=Plain shrikhand without microwave treatment. T1=Plain shrikhand with microwave treatment, T2=Enriched shrikhand without microwave treatment, T3= Enriched shrikhand with microwave treatment 
Table.4 Effect of continuous microwave treatment on the chemical composition of stored enriched shrikhand at $30 \pm 1^{0} \mathrm{C}$

\begin{tabular}{|c|c|c|c|c|c|}
\hline \multicolumn{6}{|l|}{$1^{\text {st }}$ Day } \\
\hline \multirow[t]{2}{*}{ Treatment } & Moisture & Fat & Protein & \multirow{2}{*}{$\begin{array}{l}\text { Acidity } \\
\text { (\%LA) }\end{array}$} & \multirow{2}{*}{$\begin{array}{l}\text { FFA } \\
(\mu \text { equl/g) }\end{array}$} \\
\hline & \multicolumn{3}{|c|}{--------------- Per cent -------------- } & & \\
\hline Control $(0 \%)$ & $41.53 \mathrm{a}$ & 6.82 & $7.12^{\mathrm{a}}$ & $1.210^{\mathrm{a}}$ & $0.426^{\mathrm{a}}$ \\
\hline T1 & $41.07 \mathrm{~b}$ & 6.95 & $7.48^{\mathrm{b}}$ & $1.200^{\mathrm{b}}$ & $0.383^{\mathrm{b}}$ \\
\hline T2 & $39.60 \mathrm{c}$ & 6.75 & $8.75^{\mathrm{c}}$ & $1.213^{\mathrm{a}}$ & $0.408^{\mathrm{a}}$ \\
\hline T3 & $38.73 d$ & 6.87 & $9.98^{\mathrm{d}}$ & $1.204^{\mathrm{b}}$ & $0.361^{\mathrm{b}}$ \\
\hline CD & 0.31 & NS & 0.30 & 0.008 & 0.025 \\
\hline \multicolumn{6}{|l|}{$2^{\text {nd }}$ Day } \\
\hline Control (0\%) & $41.06^{\mathrm{a}}$ & 6.89 & $7.31^{\mathrm{a}}$ & $1.270^{\mathrm{a}}$ & $0.552^{\mathrm{a}}$ \\
\hline T1 & $40.66^{\mathrm{b}}$ & 7.01 & $7.52^{\mathrm{b}}$ & $1.205^{\mathrm{b}}$ & $0.418^{\mathrm{b}}$ \\
\hline $\mathrm{T} 2$ & $39.18^{c}$ & 6.82 & $8.89^{c}$ & $1.278 \mathrm{a}$ & $0.540^{\mathrm{a}}$ \\
\hline T3 & $38.12^{\mathrm{d}}$ & 6.94 & $10.01^{\mathrm{d}}$ & $1.265^{\mathrm{b}}$ & $0.402^{b}$ \\
\hline CD & 0.47 & NS & 0.017 & 0.011 & 0.013 \\
\hline \multicolumn{6}{|l|}{$3^{\text {rd }}$ Day } \\
\hline Control & \multicolumn{5}{|l|}{ Spoiled } \\
\hline $\mathrm{T1}$ & 40.15 & 7.22 & 7.81 & 1.275 & 0.487 \\
\hline $\mathrm{T} 2$ & \multicolumn{5}{|l|}{ Spoiled } \\
\hline $\mathrm{T3}$ & 37.69 & 7.04 & 10.21 & 1.359 & 0.461 \\
\hline
\end{tabular}

Values are average of three trials, Control=Plain shrikhand without microwave treatment, T1=Plain shrikhand with microwave treatment, T2=Enriched shrikhand without microwave treatment, T3= Enriched shrikhand with microwave treatment

Table.5 Effect of continuous microwave treatment on the chemical composition of stored enriched shrikhand at $7 \pm 1^{\circ} \mathrm{C}$

\begin{tabular}{|c|c|c|c|c|c|}
\hline \multirow[t]{2}{*}{ Treatment } & Moisture & Fat & Protein & \multirow{2}{*}{$\begin{array}{l}\text { Acidity } \\
\text { (\%LA) }\end{array}$} & \multirow{2}{*}{$\begin{array}{l}\text { FFA } \\
(\mu . e q u l / g)\end{array}$} \\
\hline & \multicolumn{3}{|c|}{-------------- Per cent -------------- } & & \\
\hline Control $(0 \%)$ & $41.62^{\mathrm{a}}$ & 6.68 & $7.10^{\mathrm{a}}$ & $1.107^{\mathrm{a}}$ & $0.318^{\mathrm{a}}$ \\
\hline T1 & $41.23^{\mathrm{b}}$ & 6.80 & $7.33^{b}$ & $1.104^{\mathrm{b}}$ & $0.282^{b}$ \\
\hline T2 & $39.71^{\mathrm{c}}$ & 6.61 & $8.62^{c}$ & $1.110^{\mathrm{a}}$ & $0.321^{\mathrm{a}}$ \\
\hline T3 & $39.51^{\mathrm{d}}$ & 6.72 & $9.63^{\mathrm{d}}$ & $1.106^{\mathrm{b}}$ & $0.279^{\mathrm{b}}$ \\
\hline CD & 0.13 & NS & 0.21 & 0.004 & 0.006 \\
\hline \multicolumn{6}{|l|}{$14^{\text {th }}$ Day } \\
\hline Control $(0 \%)$ & $41.13^{\mathrm{a}}$ & 6.76 & $7.12^{\mathrm{a}}$ & $1.138^{\mathrm{a}}$ & $0.340^{\mathrm{a}}$ \\
\hline T1 & $40.76^{\mathrm{b}}$ & 6.86 & $7.28^{\mathrm{b}}$ & $1.112^{\mathrm{b}}$ & $0.292^{\mathrm{b}}$ \\
\hline $\mathrm{T} 2$ & $39.63^{c}$ & 6.69 & $8.74^{c}$ & $1.142^{\mathrm{a}}$ & $0.328^{\mathrm{a}}$ \\
\hline $\mathrm{T3}$ & $39.16^{\mathrm{d}}$ & 6.79 & $9.45^{\mathrm{d}}$ & $1.116^{\mathrm{b}}$ & $0.263^{\mathrm{b}}$ \\
\hline CD & 0.36 & NS & 0.15 & 0.003 & 0.028 \\
\hline \multicolumn{6}{|l|}{$21^{\text {st }}$ Day } \\
\hline Control $(0 \%)$ & $40.53^{\mathrm{a}}$ & 6.82 & $7.15^{\mathrm{a}}$ & $1.189^{\mathrm{a}}$ & $0.342^{\mathrm{a}}$ \\
\hline T1 & $40.46^{\mathrm{b}}$ & 6.90 & $7.30^{\mathrm{b}}$ & $1.123^{\mathrm{b}}$ & $0.289^{b}$ \\
\hline $\mathrm{T} 2$ & $39.60^{c}$ & 6.75 & $8.79^{c}$ & $1.195^{\mathrm{a}}$ & $0.331^{\mathrm{a}}$ \\
\hline T3 & $38.00^{\mathrm{d}}$ & 6.83 & $9.47^{\mathrm{d}}$ & $1.135^{\mathrm{b}}$ & $0.281^{\mathrm{b}}$ \\
\hline CD & 0.11 & NS & 0.13 & 0.009 & 0.005 \\
\hline
\end{tabular}

Values are average of three trials, Control=Plain shrikhand without microwave treatment, T1=Plain shrikhand with microwave treatment, T2=Enriched shrikhand without microwave treatment, T3= Enriched shrikhand with microwave treatment 
Table.6 Effect of continuous microwave treatment on the chemical composition of stored enriched shrikhand at $7 \pm 1^{\circ} \mathrm{C}$

\begin{tabular}{|c|c|c|c|c|c|}
\hline \multicolumn{6}{|l|}{$28^{\text {in }}$ Day } \\
\hline Treatment & Moisture & Fat & Protein & \multirow{2}{*}{$\begin{array}{l}\text { Acidity } \\
\text { (\%LA) }\end{array}$} & \multirow{2}{*}{$\begin{array}{l}\text { FFA } \\
(\mu \text { equl/g }\end{array}$} \\
\hline & \multicolumn{3}{|c|}{ 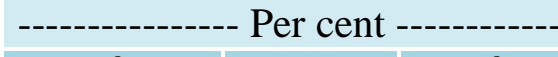 } & & \\
\hline Control (0\%) & $40.05^{\mathrm{a}}$ & 6.87 & $7.18^{\mathrm{a}}$ & $1.218^{\mathrm{a}}$ & $0.353^{\mathrm{a}}$ \\
\hline T1 & $39.96^{\mathrm{b}}$ & 6.94 & $7.33^{\mathrm{b}}$ & $1.147^{\mathrm{b}}$ & $0.316^{\mathrm{b}}$ \\
\hline $\mathrm{T} 2$ & $39.50^{c}$ & 6.80 & $8.84^{\mathrm{c}}$ & $1.224^{\mathrm{a}}$ & $0.351^{\mathrm{a}}$ \\
\hline T3 & $37.80^{\mathrm{d}}$ & 6.88 & $9.49^{\mathrm{d}}$ & $1.149^{\mathrm{b}}$ & $0.298^{\mathrm{b}}$ \\
\hline CD & 0.31 & NS & 0.12 & 0.054 & 0.032 \\
\hline \multicolumn{6}{|l|}{$35^{\text {th }}$ Day } \\
\hline Control (0\%) & $39.06^{\mathrm{a}}$ & 6.98 & $7.29^{\mathrm{a}}$ & $1.245^{\mathrm{a}}$ & $0.461^{\mathrm{a}}$ \\
\hline T1 & $38.97^{b}$ & 7.06 & $7.42^{b}$ & $1.189^{\mathrm{b}}$ & $0.412^{b}$ \\
\hline T2 & $39.47^{\mathrm{c}}$ & 6.92 & $8.93^{\mathrm{c}}$ & $1.258^{\mathrm{a}}$ & $0.416^{\mathrm{a}}$ \\
\hline T3 & $37.30^{\mathrm{d}}$ & 7.01 & $9.52^{\mathrm{d}}$ & $1.199^{\mathrm{b}}$ & $0.362^{b}$ \\
\hline CD & 0.22 & NS & 0.11 & 0.030 & 0.060 \\
\hline \multicolumn{6}{|l|}{$42^{\text {nd }}$ Day } \\
\hline Control (0\%) & \multicolumn{5}{|c|}{ Spoiled on $36^{\text {th }}$ day } \\
\hline T1 & $38.50^{\mathrm{b}}$ & 7.27 & $7.63^{\mathrm{b}}$ & $1.227^{\mathrm{b}}$ & $0.463^{\mathrm{b}}$ \\
\hline T2 & $38.35^{\mathrm{c}}$ & 7.13 & $9.06^{\mathrm{c}}$ & $1.510^{\mathrm{a}}$ & $0.791^{\mathrm{a}}$ \\
\hline T3 & $36.27^{\mathrm{d}}$ & 7.12 & $9.63^{\mathrm{d}}$ & $1.249^{b}$ & $0.461^{\mathrm{b}}$ \\
\hline CD & 0.10 & NS & 0.21 & 0.090 & 0.030 \\
\hline \multicolumn{6}{|l|}{$49^{\text {th }}$ Day } \\
\hline T1 & 38.11 & 7.31 & 7.68 & 1.322 & 0.481 \\
\hline T3 & 36.09 & 7.21 & 9.81 & 1.350 & 0.478 \\
\hline
\end{tabular}

Values are average of three trials, Control=Plain shrikhand without microwave treatment, T1=Plain shrikhand with microwave treatment. T2=Enriched shrikhand without microwave treatment, T3= Enriched shrikhand with microwave treatment

Table.7 Effect of continuous microwave treatment on microbiological quality of shrikhand at $30 \pm 1^{\circ} \mathrm{C}$

\begin{tabular}{|c|c|c|c|c|c|c|c|c|c|}
\hline \multirow[t]{3}{*}{ Treatments } & \multicolumn{9}{|c|}{ Counts expressed in $\log _{10} c f u / g$} \\
\hline & \multicolumn{2}{|c|}{0 Day } & \multicolumn{2}{|c|}{1 Day } & \multicolumn{2}{|l|}{2 Day } & \multicolumn{2}{|c|}{3 day } & \multirow[t]{2}{*}{4 day } \\
\hline & TC & YM & TC & YM & TC & YM & TC & YM & \\
\hline Control (0\%) & $2.70^{\mathrm{a}}$ & $1.20^{\mathrm{a}}$ & $3.63^{\mathrm{a}}$ & $1.84^{\mathrm{a}}$ & $4.28^{\mathrm{a}}$ & $1.95^{\mathrm{a}}$ & \multicolumn{3}{|c|}{ Spoiled } \\
\hline T1 & $1.15^{\mathrm{b}}$ & $1.00^{\mathrm{b}}$ & $2.60^{\mathrm{b}}$ & $1.42^{\mathrm{b}}$ & $3.20^{\mathrm{b}}$ & $1.60^{\mathrm{b}}$ & 4.08 & 1.86 & Spoiled \\
\hline T2 & $3.02^{\mathrm{a}}$ & $1.62^{\mathrm{a}}$ & $3.78^{\mathrm{a}}$ & $1.89^{\mathrm{a}}$ & $4.52^{\mathrm{a}}$ & $1.97^{\mathrm{a}}$ & \multicolumn{3}{|c|}{ Spoiled } \\
\hline$\overline{T 3}$ & $1.20^{\mathrm{b}}$ & $1.12^{\mathrm{b}}$ & $2.78^{\mathrm{b}}$ & $1.63^{\mathrm{b}}$ & $3.55^{\mathrm{b}}$ & $1.70^{\mathrm{b}}$ & 4.36 & 2.00 & Spoiled \\
\hline CD & 1.5 & 0.43 & 0.85 & 0.22 & 0.51 & 0.22 & NS & NS & \\
\hline
\end{tabular}

Values are average of three trials, $\mathrm{TC}=$ Total Count, $\mathrm{YM}=$ Yeast and Mould Count, Control $=$ Plain shrikhand without microwave treatment, T1=Plain shrikhand with microwave treatment, T2 =Enriched shrikhand without microwave treatment, T3 = Enriched shrikhand with microwave treatment 
Table.8 Effect of continuous microwave treatment on microbiological quality of shrikhand at $7 \pm 1^{\circ} \mathrm{C}$

\begin{tabular}{|c|c|c|c|c|c|c|c|c|c|c|c|c|c|c|}
\hline \multirow[t]{3}{*}{ Treatments } & \multicolumn{14}{|c|}{ Counts expressed in $\log _{10} c f u / g$} \\
\hline & \multicolumn{2}{|c|}{$7^{\text {th }}$ Day } & \multicolumn{2}{|c|}{$14^{\text {th }}$ Day } & \multicolumn{2}{|c|}{$21^{\text {st }}$ Day } & \multicolumn{2}{|c|}{$28^{\text {th }}$ Day } & \multicolumn{2}{|c|}{$35^{\text {th }}$ Day } & \multicolumn{2}{|c|}{$42^{\text {nd }}$ Day } & \multicolumn{2}{|c|}{$49^{\text {th }}$ Day } \\
\hline & TC & $\mathbf{Y M}$ & $\mathbf{T C}$ & $\mathbf{Y M}$ & TC & $\mathbf{Y M}$ & TC & $\mathbf{Y M}$ & TC & YM & $\mathbf{T C}$ & $\mathbf{Y M}$ & TC & YM \\
\hline Control (0\%) & $2.80^{\mathrm{a}}$ & $1.28^{\mathrm{a}}$ & $2.91^{\mathrm{a}}$ & $1.35^{\mathrm{a}}$ & $2.96^{\mathrm{a}}$ & $1.52^{\mathrm{a}}$ & $3.00^{\mathrm{a}}$ & $1.59^{\mathrm{a}}$ & $3.50^{\mathrm{a}}$ & $1.92^{\mathrm{a}}$ & Spoi & & & \\
\hline T1 & $1.30^{\mathrm{b}}$ & $1.00^{\mathrm{b}}$ & $1.88^{\mathrm{b}}$ & $1.08^{\mathrm{b}}$ & $1.92^{\mathrm{b}}$ & $1.13^{\mathrm{b}}$ & $2.01^{b}$ & $1.40^{\mathrm{b}}$ & $2.23^{b}$ & $1.60^{\mathrm{b}}$ & 2.66 & 1.72 & 3.82 & 1.88 \\
\hline $\mathrm{T2}$ & $3.20^{\mathrm{a}}$ & $1.68^{\mathrm{a}}$ & $3.33^{\mathrm{a}}$ & $1.70^{\mathrm{a}}$ & $3.40^{\mathrm{a}}$ & $1.82^{\mathrm{a}}$ & $3.51^{\mathrm{a}}$ & $1.90^{\mathrm{a}}$ & $3.60^{\mathrm{a}}$ & $2.00^{\mathrm{a}}$ & Spoi & & & \\
\hline T3 & $1.33^{b}$ & $1.17^{b}$ & $1.96^{b}$ & $1.20^{\mathrm{b}}$ & $2.04^{b}$ & $1.32^{b}$ & $2.30^{b}$ & $1.50^{b}$ & $2.48^{\mathrm{b}}$ & $1.70^{b}$ & 2.78 & 1.82 & 4.42 & 1.99 \\
\hline CD & 1.08 & 0.42 & 0.95 & 0.37 & 0.85 & 0.38 & 0.80 & 0.43 & 0.30 & 0.33 & & & & \\
\hline
\end{tabular}

Values are average of three trials, $\mathrm{TC}=$ Total Count, $\mathrm{YM}=$ Yeast and Mould Count, Control=Plain shrikhand without microwave treatment, T1 =Plain shrikhand with microwave treatment, T2 =Enriched shrikhand without microwave treatment T3 = Enriched shrikhand with microwave treatment

There was significantly higher per cent of protein was recorded for T3 (9.98) compared to control (7.12). This could be mainly due to the added WPC to the product, whereas, fat contents of the control and treated samples were found to be non-significant on $1^{\text {st }}$ day of storage. But, there was a significantly lower per cent of acidity (1.204 \% LA) was recorded for the WPC enriched and microwave treated sample (T3) compared to control (1.210 \%LA). The control sample recorded higher levels of FFA compared to treated samples. The lower levels of acidity and FFA contents of the microwave treated samples could be due to the lower microbial counts (Table 7).

There was a significant decrease in the per cent of moisture content of T3 sample (38.12 $\%)$ compared to control (41.06\%) was observed on $2^{\text {nd }}$ day of storage at $30 \pm 1^{\circ} \mathrm{C}$. The lower levels of moisture content in the treated samples sample could be due to loss of moisture during storage, microwave treatment in addition to added WPC. Similarly T3 recorded significantly higher per cent of protein $(10.01 \%)$ compared to the samples without having WPC, whereas, per cent fat contents of the control and treated samples were found to be non-significant on $2^{\text {nd }}$ day of storage. But, there was a significantly lower per cent of acidity (1.265\%LA) was recorded for the WPC enriched and microwave treated sample (T3) compared to control (1.270 \%LA). Again, control sample recorded higher levels of FFA compared to treated samples at the end of the $2^{\text {nd }}$ day storage.

There was a significant decrease in the per cent of moisture content of T1 (40.15\%), T2 (38.01\%), T3 (37.69 \%) compared to control sample $(40.56 \%)$ was recorded on $3^{\text {rd }}$ day of storage at $30 \pm 1^{\circ} \mathrm{C}$ (Table 4). The per cent fat contents of the control and treated samples were found to be non-significant change on $3^{\text {rd }}$ day of storage and significantly higher per cent of protein was recorded for the T3 (10.21 $\%)$ sample compared to control $(7.65 \%)$ and T1(7.81\%). But, significantly lower per cent of acidity (1.359\% LA) was recorded for the WPC enriched and microwave treated sample (T3) compared to control (1.440 \%LA). The control sample recorded significantly higher levels of FFA $(0.870 \mu$ equl/g) compared to $\mathrm{T} 1(0.481 \mu$ equl/g and T3 $(0.481 \mu$ equl/g) treated samples. The lower levels of acidity and FFA contents of the microwave treated samples could be due to the lower microbial counts as recorded in Table 7. On $4^{\text {th }}$ day T1 and as well as T3 was recorded higher levels of FFA contents at $30 \pm 1^{\circ} \mathrm{C}$.

Jha and Bargale (1999) demonstrated that the shelf-life of soya-paneer could be extended to 
15 days at refrigeration by submerged heating of paneer in polyethylene to $75^{\circ} \mathrm{C}$ for 30 minutes in a water bath. Arunkumar, (2006), revealed the effect of microwave and vacuum packaging on the chemical quality of paneer spread. Fresh paneer spread showed significantly lower moisture content than untreated paneer spread. Fat, protein, pH, soluble nitrogen and FFA were not much affected by microwave, vacuum package and their combination treatments. During storage at $30 \pm 1^{\circ} \mathrm{C}$, the treated paneer spreads showed lower increase in soluble nitrogen, FFA and lower decrease in moisture and $\mathrm{pH}$ than control. Karthikeyan, (2005), also observed the same results in the preparation of paneer which was exposed to continuous microwave treatment.

\section{Effect of continuous microwave treatment chemical quality of enriched shrikhand stored at $7 \pm 1^{\circ} \mathrm{C}$}

The sample T3 recorded significantly lower per cent of moisture (39.51) compared to control (41.62) on $7^{\text {th }}$ day of storage at $7 \pm 1^{\circ} \mathrm{C}$ (Table 5). The lower levels of moisture content in the enriched samples could be due to microwave treatment in addition to added WPC. Whereas, per cent fat content of the control and treated samples were found to be non-significant on $7^{\text {th }}$ day of storage. The protein per cent of T3 (9.63) was recorded significantly higher than that of control (7.10) on $7^{\text {th }}$ day of storage at refrigerated temperature. But, there was a significantly lower per cent of acidity (1.104 \%LA) was recorded for the T3 sample compared to control (1.107 \%LA). The control sample recorded higher levels of FFA compared to treated samples.

The lower levels of acidity and FFA contents of the microwave treated samples could be attributed to the lower microbial counts (Table 6).
There was a significant decrease in the per cent of moisture content of T3 sample (39.16) compared to control (41.13) was observed on $14^{\text {th }}$ day of storage at $7 \pm 1^{\circ} \mathrm{C}$, whereas, per cent fat content of the control and treated samples were found to be non-significant. But, there was a significant increase in the protein per cent was observed in WPC incorporated sample. Lower per cent of acidity $(1.116 \%$ LA) was recorded for the WPC enriched and microwave treated sample (T3) compared to control (1.138 \% LA). Control sample recorded higher levels of FFA compared to treated samples at the end of the $14^{\text {th }}$ day storage.

There was a significant decrease in the per cent of moisture content of T1 (40.46\%), T2 (39.60\%), T3 (38.0\%) compared to control sample $(40.53 \%)$ was recorded on $21^{\text {st }}$ day of storage at $7 \pm 1^{\circ} \mathrm{C}$. The per cent fat content of the control and treated samples were found to be non-significant on $21^{\text {st }}$ day of storage. But, protein per cent was found to be higher in T3 compared to control. There was a significantly lower per cent of acidity (1.125 \%LA) was recorded for the WPC enriched and microwave treated sample (T3) compared to control (1.189 \%LA). The control sample had significantly higher levels of FFA (0.342 $\mu$ equl/g) compared to T3 $(0.281 \mu$ equl $/ \mathrm{g})$. The results of the present findings are in agreement with Karthikeyan (2005). Similarly, There was a significant decrease in the per cent of moisture content of T3 was observed up to $49^{\text {th }}$ day of storage at $7 \pm 1^{\circ} \mathrm{C}$ due to incorporation of WPC and microwave treatment. The fat per cent of all the samples showed no significant change throughout storage. But, the protein per cent of the sample T3 recorded significantly higher than the control up to $49^{\text {th }}$ days of storage. The per cent lactic acid and FFA of control had significantly higher values than the enriched and microwave treated sample T3. The product exposed to microwave treatment may 
leads to destruction of microorganism and enzymes as a result lower microbial changes was observed (Table 8). The results are in agreement with karthikeyan (2005).

\section{Storage studies on microbial quality of enriched shrikhand}

Effect of continuous microwave treatment microbial quality of enriched shrikhand fresh and stored at $30 \pm 1^{\circ} \mathrm{C}$

The untreated shrikhand sample (control) had significantly high total counts of $2.70 \log _{10}$ $\mathrm{cfu} / \mathrm{g}$ compared to continuous microwave treated T1 (1.15 $\left.\log _{10} \mathrm{cfu} / \mathrm{g}\right)$, T3 (1.20 $\log _{10}$ cfu/g), Similarly, control recorded significantly higher total counts upto 2 days of storage than those of treated samples at $30 \pm 1^{\circ} \mathrm{C}$ (Table 7). The control sample had yeast and mould counts of $1.20 \log _{10} \mathrm{cfu} / \mathrm{g}$. On further storage, upto 3 days, the yeast and mould counts were continued to be increased to $1.95 \log _{10} \mathrm{cfu} / \mathrm{g}$. But T3 sample recorded significantly lower total counts and as well as lower yeast and moulds counts upto 3 days of storage was found to well within the limits of standards. On $3^{\text {rd }}$ day, enriched and microwave treated sample (T3) recorded 0.23 and $0.15 \log _{10} \mathrm{cfu} / \mathrm{g}$ counts of total counts and yeast and mould counts respectively.

Prajapati et al., (1990), recorded that, there was corresponding reduction of counts in heat treated shrikhand samples. Shrikhand was prepared by heating at $55^{\circ} \mathrm{C}$ for 30 minutes (T1), $60^{\circ} \mathrm{C}$ for 20 minutes (T2), $65^{\circ} \mathrm{C}$ for 10 minutes (T3), $70^{\circ} \mathrm{C}$ for 5 minutes (T4) and $75^{\circ} \mathrm{C}$ for 2 minutes (T5) and counts recorded were $61.92,66.13,74.13,78.79$ and 82.47 for total viable count respectively. Yeast and moulds survived in $\mathrm{T} 1$ and $\mathrm{T} 2$ treatments by 85.38 and $27.14 \%$ respectively. Villamiel et al., (1996) showed that microwave pasteurization of milk resulted in lower microbial counts.
Effect of continuous microwave treatment microbial quality of enriched shrikhand stored at $7 \pm 1^{\circ} \mathrm{C}$

The effect of microwave treatment on microbial quality of enriched shrikhand stored at $7 \pm 1^{\circ} \mathrm{C}$ is presented in the Table 8. The control and T2 had significantly higher total counts as compared to T1 and T3 upto 35 days of storage and afterwards samples were rejected. Among the samples T1 and T3 recorded significantly lower counts than those of control and T2 shrikhand samples upto 35 days of storage. The lower counts could be due to the combined effect of microwave treatment and moisture content was comparatively lesser than the control sample and also microwave treatment that would have restricted the growth of microorganisms.

Similarly, yeast and mould counts of control and T2 had scientifically higher than the treated samples (T1 and T3) and the trend was continued upto $35^{\text {th }}$ day of storage. But T3 and T1 samples (microwave treated) sample recorded comparatively less counts than the control. The yeast and moulds counts of T3 were 1.82 and $1.99 \log _{10} \mathrm{cfu} / \mathrm{g}$, respectively. Similar results were reported by Karthikeyan (2005). In present investigation shrikhand was enriched with different levels of WPC at 3, 4, 5 and 6 per cent levels and Maximum overall acceptability score of 8.20 was awarded to the sample prepared by using WPC at 5 per cent level which enhances functional and nutritional properties of shrikhand. The product shelf-life is increased up to 49 days at refrigerated temperature by microwave processing when to conventional processing

\section{References}

Aneja, R.P., M.N. Vyas, K. Nanda and Thareja V.K. 1997. Development of an industrial process for the manufacture 
of shrikhand. Journal of Food Science and Technology, India, 14(4): 159-163

Arunkumar, H. 2006. Development of various paneer based spreads, Thesis submitted to Karnataka Veterinary, Animal and Fisheries Sciences University, Bidar, India.

Busra, A., and Nermin, B. 2014. Effect of whey protein concentrate and buttermilk powders on rheological properties of dough and bread quality. Journal of Food Quality, 37(2): 117-124

Giram, S.D., R.P. Barbind, V.D. Pawar, B.K. Sakhale, and Agarkar, B.S. 2001. Studies of fortification of sour whey concentrate in Chakka for preparation of Shrikhand. Journal of Food Science and Technology Mysore. 38(3): 294-29

Gupta, V.K., and Thapa, T.B. 1991. Application of whey protein concentrates in food industry. Indian. J.Dairy Sci., 44(1): 104-108

Gupta, V.K., and Thapa, T.B. 1991. Application of whey protein concentrates in food industry. Indian. J. Dairy Sci., 44(1): 104-10

Irvine, D.M., A. Hill and Bullock D.H. 1984. Development in the whey protein for human consumption. Modern dairy, 63(4):18-23

Jayaprakasha, H.M., and Brueckner, H. 1999. Whey protein concentrate: A potential functional food ingredient for food industry. J. Food Sci. Technol., 36(3): 189-204

Jha. K., and Bargle, P.C. 1999. A study on shelf-life of Soya paneer in different packaging system. J. Dairying Foods Home Sci. 18 (3-4):228-231.
Karthikeyan, S. 2005. Application of continuous microwave processing and modified atmosphere packaging for enhancement of Shelf life of paneer. Thesis submitted to Karnataka Veterinary, Animal and Fisheries Sciences University Bidar, India.

Mullin, J. 1995. Microwave processing, cited in "New Methods of Food Preservation" edited by Gould, G.W., Pub. Blackie Academic and Professional, London, pp. 112

Ohlsson, T., and Bengtsson, N. 2002. Minimal processing technologies in the food industry. Woodhead Publ. Co. England. pp 23-27

Puranik, D.B., and Gupta, S.K. 1997. Development of cake mixes using milk by- products as egg substitutes, Annual report, NDRI, Karnal, Page 27

Renner, E., 1983. Milk and Dairy Products in Human Nutrition, Volksw, Verlag, Munchen.

Suneeta, P., A.K. Rathour, A.K. Prajapati, J.P. Jana and Solanky, M.J. 2007. Utilization of whey protein concentrates in processed cheese spread. Natural Product Radiance, 6(5):398-401

Tamine, A.Y., and Robinson, R.K. 2007. Yoghurt. Science and technology (3rd ed.). Boca Raton, Boston, New York, Washington, DC: CRC Press.

Thapa, T.B., and Gupta, V.K. 1992. Changes in sensoric and rheological characteristics during storage of processed cheese foods prepared with added whey protein concentrates. Indian J. Dairy Sci., 45(3):140-145

\section{How to cite this article:}

Venkatesh, M., T.C. Soumyashree, M. Rajanna and Praveen, A.R. 2018. Extension of Shelf Life of Enriched Shrikhand Using Continues Microwave Processing. Int.J.Curr.Microbiol.App.Sci. 7(04): 3272-3283. doi: https://doi.org/10.20546/ijcmas.2018.704.371 